\title{
Preliminary report on $\beta$-casein gene Met183QVal183 polymorphism in Romanian indigenous Zackel sheep breeds
}

\author{
Szilvia Kusza1,2凶, Daniela Elena Ilie ${ }^{1,3}$, Maria Sauer ${ }^{1}$, Ioan-Walter Sauer ${ }^{1}$ and Dinu Gavojdian ${ }^{1}$ \\ ${ }^{1}$ Research and Development Station for Sheep and Goats Caransebes, Academy for Agricultural and Forestry Sciences, 325400, Caransebes, \\ Romania; ${ }^{2}$ Institute of Animal Science, Biotechnology and Nature Conservation, University of Debrecen, 4032, Debrecen, Hungary; ${ }^{3}$ Research \\ and Development Station for Bovine Arad, Academy for Agricultural and Forestry Sciences, 317236, Arad, Romania
}

Genetic polymorphisms of the milk protein genes are important because of their effects on quantitative traits and technological properties of milk manufacturing. In the present study we identified the polymorphism of the beta-casein gene in two local sheep breeds (Racka $\mathrm{n}=98$ and Turcana $\mathrm{n}=111$ ) in Romania. The most studied variants at the ovine beta-casein (CSN2) locus are: A and G variants. Genomic DNA was extracted from hair follicles and beta-casein genotypes were determined by the rapid TaqMan (Applied Biosystems, USA) genotyping assay. Homozygote genotypes GG were not detected in any of the studied breeds. In both, the Racka and Turcana breeds, the A variant had a much higher frequency, $0.98 \%$ and $0.97 \%$, respectively. In the current study, the fast DNA tests for genotyping ovine CSN2 were successfully optimized, however, further samples and correlations of genomic results with milk characteristics and production data are needed for the development of future selection schemes of the Romanian indigenous sheep breeds, with the ultimate purpose to produce low allergen level sheep milk and derived dairy products.

Key words: $\beta$-casein, gene polymorphism, ovine milk, Racka, Turcana Received: 05 October, 2016; revised: 21 February, 2017; accepted: 28 February, 2017; available on-line: 17 May, 2017

e-mail: kusza@agr.unideb.hu

Abbreviations: CSN2, $\beta$-casein gene; DNA, deoxyribonucleic acid $\mathrm{PCR}$, polymerase chain reaction; CSN1S1, aS1-casein gene; $\mathrm{CN}$, casein; $\beta$-LG, $\beta$-lactoglobulin; $a-L A$, $a$-lactalbumin

\section{INTRODUCTION}

Studies on the genetic polymorphism of milk proteins have recently received considerable interest from animal geneticists and the dairy industry. Studies on sheep milk protein polymorphism and its effects on milk yields of sheep are principally carried out in the Mediterranean countries (Italy, France and Spain), in which great importance is given to implications in milk performance (Mroczkowski et al., 2004).

Zackel is the name of an old Egyptian phyletic group of sheep breeds, indigenous to Central-, Eastern and Southern Europe (Draganescu, 1997; Draganescu \& Grosu, 2010). Zackel sheep are very well adapted to extensive production conditions and are regarded as lowinput breeds. Milk production varies greatly between the Zackel sheep, mainly because of the different feeding management of flocks. Average milk production could be considered low or medium, with yields varying from 70 to $150 \mathrm{~kg}$ of milk/lactation (Padeanu, 2001; Gavojdian et al., 2013).
The Turcana breed belonging to the Zackel group is economically the most important breed in Romania nowadays (over 6 million breeding ewes), while the Racka is listed as endagered, with a census of less than 3000 breeding ewes. Rams from both breeds are about $60-80 \mathrm{~kg}$, while ewes are between 40 to $55 \mathrm{~kg}$. Zackel sheep are found in Romania, Hungary, Austria, the Czech Republic, Slovakia, Ukraine, Moldavia, Greece, Turkey, Albania, Poland and the former Yugoslavian countries. Turcana and Racka milk is used for dairy products such as hard cheeses (Telemea) while the wool is used in the textile industry, and the lamb meat is either consumed at Easter celebrations or exported to the Arab states market (Padeanu et al., 2004; Pariset et al., 2006; Ilisiu et al., 2012).

The main milk proteins are the same in sheep, goats and cows. Two classes can be distinguished: caseins and whey proteins. The caseins of ruminant milk proteins contains four caseins, namely $\alpha \mathrm{s} 1-, \alpha \mathrm{s} 2-, \beta$-and $\mathrm{K}$-casein and they are linked within a $250 \mathrm{~kb}$ cluster (Threadgill \& Womack, 1990; Leveziel et al., 1991; Bevilacqua et al., 2006; Park et al., 2007) at the ovine chromosome 6 (Gortari et al., 1998).

Among the ovine caseins, the $\beta$-casein is the most abundant with an average content of $>50 \%$ (Dove, 2000). At first, Provot and coworkers (1995) published the full sequence of ovine $\beta$-casein gene (accession number: X79703.1). The gene has nine exons that are short with the exception of exon 7 which is included in the coding region, and exon 9 (492- and 323-bp respectively). It was thought that the $\beta$-casein had only a non-genetic polymorphism due to varying level of phosphorylation, until Chianese and coworkers (1997) distinguished among the three genetic variants of $\beta$-casein, namely $A$, $\mathrm{B}$, and, C. DNA-based studies demonstrated polymorphisms within the coding sequence of the ovine CSN2 like an $A>G-S N P$ lying within exon 7 and leading to the deduced amino acid exchange p.Met183Val (Bastos et al., 2001; Ceriotti et al., 2004, Chessa et al., 2010; Corral et al., 2010, 2013).

Aim of the current research was to identify the genetic polymorphism of the $\beta$-casein gene in two indigenous dairy sheep breeds belonging to the Zackel group (Racka and Turcana), by the use of a TaqMan genotyping assay, in order to provide information for future selection schemes of the Romanian indigenous sheep breeds, with the ultimate further purpose to produce low allergen level sheep milk and derived dairy products.

\section{MATERIAL AND METHODS}

Samples and DNA extraction. Altogether, 209 animals from two indigenous Romanian sheep breeds 
(Racka $\mathrm{n}=98$, from the Caras-Severin and Timis counties, Fig. 1; and Turcana $\mathrm{n}=111$, from the Arad, CarasSeverin, Hunedoara and Timis counties, Fig. 2) were sampled in the present study to detect genetic polymorphism at the CSN2 locus.

Hair follicles were collected from adult breeding ewes, between 1.5 and 8 years old, with balanced age and parity within the flocks and representing a diverse sampling of genetic lines for each of the two breeds. All commercial farms that reared Racka and Turcana breeds included in this study, were included in the official performance recording system, with ancestry of the animals known for at least two generations.

Extraction of genomic DNAs from hair follicles was performed by using a method of FAO/IAEA (2004), whichwas stored at $-20^{\circ} \mathrm{C}$ til further analysis. Concentration and quality of the extracted DNAs was measured and checked by a NanoDrop Spectrophotometer (Thermo Scientific, USA).

Genotyping. Taqman (Applied Biosystems, USA) genotyping probe for ovine $\beta$-casein was designed for the fast genotyping of the $A>G$ mutation present in a part of an exon 7 at position 183 (Met183QVal183). Concentration of DNA used for the genotyping assay was $50 \mathrm{ng}$.

The following primers and probe were designed by Sztankóová et al. (2011) and used: forward primer: 5'-CGTGCTGTCCCTTTCTCA-3', reverse primer: 5'-TTTT'TGAGGGCTCTTAATTACTCAA-3', probe A/G: CCCCAGAGAGAT[A/G]TGCCCATCC.

Amplification and allelic discrimation was performed with an ABI 7300 Real-Time PCR System (Applied Biosystems, USA) in a 96-well reaction plate, in $20 \mu \mathrm{l}$ reactions containing $1 \mu \mathrm{l}$ (50 ng) of genomic DNA as template, TaqMan PCR Master Mix (Life Technologies, USA), the forward and reverse primers for amplification of the polymorphic sequence, and the TaqMan probe. The time and temperature profile of PCR reaction consisted of the following steps: $95^{\circ} \mathrm{C}$ for $10 \mathrm{~min}$, followed by 40 cycles of $95^{\circ} \mathrm{C}$ for $15 \mathrm{sec}$ and $60^{\circ} \mathrm{C}$ for $1 \mathrm{~min}$. Negative control containing distilled water instead of DNA was also run in each assay.

Data analysis. After the PCR was completed, allelic discrimination analysis was performed using SDS software (Applied Biosystems, USA). The samples were automatically grouped according to their genotypes. The results of the TaqMan allelic discrimination assay were

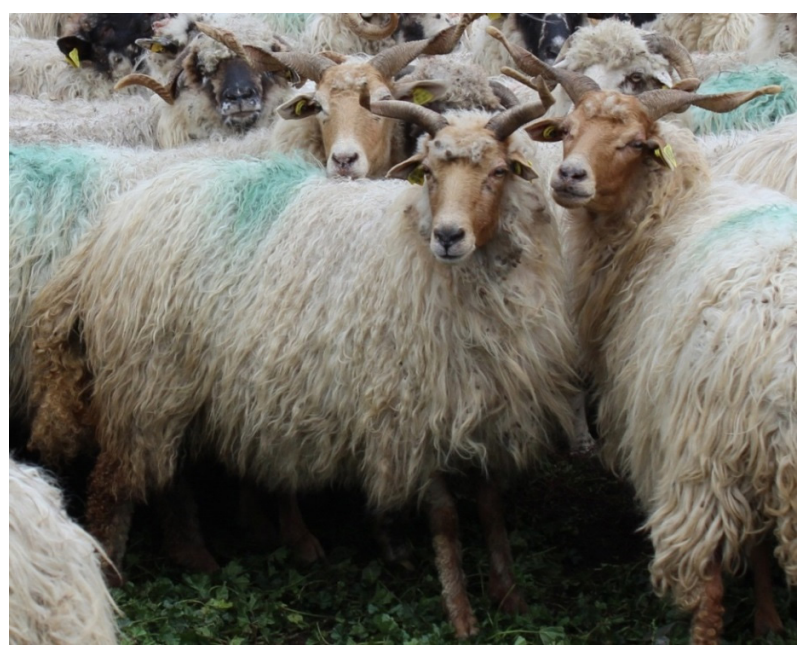

Figure 1. Racka ewes, sampling site: Ghilad, Timis county graphically interpreted and all of the samples were correctly assigned the right genotype.

Ethics statement. The research activities were performed in accordance with the European Union's Directive for animal experimentation (Directive 2010/63/EU).

\section{RESULTS AND DISCUSSIONS}

Optimization of the Taqman probe to differentiate the $A$ and $G$ allele in the Racka and Turcana sheep was successfully performed. All three genotypes and the negative control were clearly separated based on the different intensity of the alleles.

In the studied Romanian breeds, the A variant had a significantly higher frequency (Racka $=0.98$, and Turcan $a=0.97)$ compared to the $G$ variant (Racka $=0.02$, and Turcana $=0.03$ ), thus indicating that the $A$ variant is more characteristic for the Zackel sheep populations reared in Romania when compared to the $G$ variant (Table 1).

Similar results were previously reported in other European Zackel breeds, with the $\mathrm{A}$ variant being detected at a higher frequency (50 to $80 \%$ ) when compared to the $G$ variant, as reported by Sztankóová and coworkers (2011) in the Czech Sumava and Valachian sheep, and by Ceriotti and coworkers (2004) and Chessa and coworkers (2010) in the Italian sheep breeds (Comisana, Sarda, Sopravissana).

The most frequent genotype was AA $(96.94 \%$ in Racka and $94.59 \%$ in Turcana) followed by AG $(3.06 \%$ and $5.41 \%$, respectively). The GG genotype was not found in the Romanian breeds studied here (Table 1). The distribution of genotypes is in agreement with results obtained for other European sheep breeds (Ceriotti et al., 2004; Sztankóová et al., 2011).

In the sheep and goats, the number of genetic variants of milk protein genes is continually rising (Marletta et al., 2007). According to Marletta and coworkers (2004), the allergic effect of 3 casein fractions (homozygous normal, homozygous 0 and heterozygous normal) was similar. Based on the amount of samples, three levels (C20, C50, and C80) were created, according to the $\alpha$ s2-casein and seroprotein content of the sample. In the case of C50, the most allergenic was homozygous normal followed by homozygous 0 and heterozygous normal.

Cow milk allergy is the most frequent allergy occuring in the first years of life. Milk from other mammalian species has been suggested as a possible nutritional

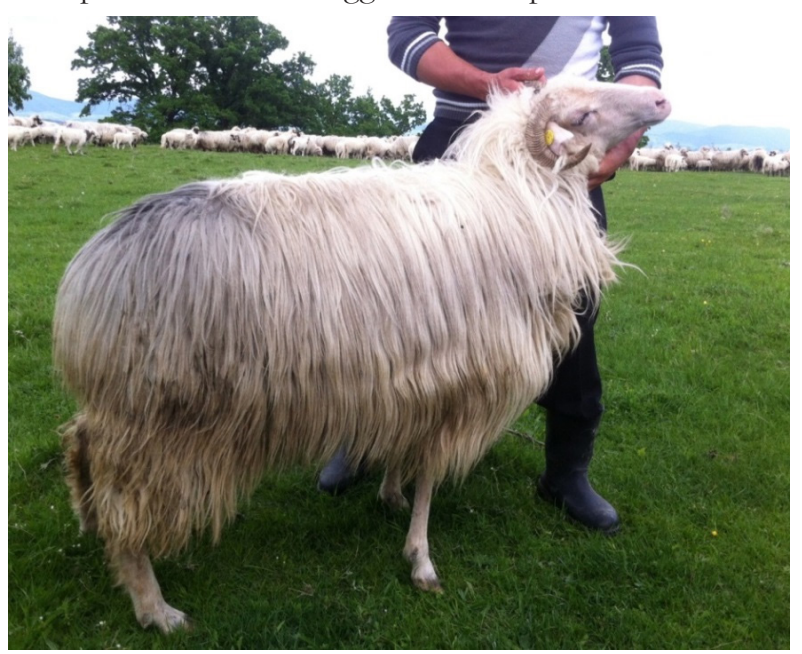

Figure 2. White faced Turcana ewe, sampling site: Salbagel, Caras-Severin county 
Table 1. Frequeny of genotype and alleles of Turcana and Racka sheep breeds

\begin{tabular}{llcccc}
\hline Breed & Genotype & Number & Frequency of genotype & Allele & Frequency of allele \\
\hline Turcana & GG & 0 & 0 & A & 0.97 \\
& AG & 6 & 5.41 & G & 0.03 \\
& AA & 105 & 94.59 & & \\
\hline Racka & GG & 0 & 0 & A & 0.98 \\
\hdashline & AG & 3 & 3.06 & G & 0.02 \\
\hline & AA & 95 & 96.94 & & \\
\hline
\end{tabular}

alternative to cow milk, but in several cases, the clinical studies had shown a high risk of cross-reactivity with cow milk. In the sheep and goat species, $\alpha \mathrm{S} 1$-casein $(\alpha \mathrm{S} 1-\mathrm{CN})$, encoded by the CSN1S1 gene, is characterized by extensive qualitative and quantitative polymorphisms. Some alleles are associated with null (i.e., $\mathrm{CSN} 1 \mathrm{~S} 1 * 01$ ) or reduced (i.e., $\mathrm{CSN} 1 \mathrm{~S} 1 * \mathrm{~F}$ ) expression of the specific protein (Ballabio et al., 2011).

Current preliminary study is a first attempt of studying polymorphism of one of the ovine milk protein genes in the Romanian breeds to produce hypoallergenic sheep milk throughout the use of genomic selection in Romania, in order to aid consumers affected by food-related allergies.

\section{CONCLUSIONS}

In the preliminary study presented here, the genetic polymorphism of ovine $\beta$-casein gene in the Romanian Zackel breeds was highlighted, using a TaqMan assay. $\beta$-casein in sheep is strongly correlated with economically important quantitative milk traits (protein and fat levels, milk solids, milk: cheese conversion ratio). However, further studies with higher numbers of animals and more breeds are needed to use this gene as a tool for the genetic improvement of indigenous breeds. Moreover, correlations between the CSN2 genotypes and milk production traits are planned to be studied in another on-going project.

\section{Acknowledgements}

This work was supported by a grant from the Romanian National Authority for Scientific Research and Innovation, CNCS - UEFISCDI, project number PN-IIRU-TE-2014-4-0023.

Krisztina Nagy is thanked for her help with the laboratory work.

\section{REFERENCES}

Ballabio C, Chessa S, Rignanese D, Gigliotti C, Pagnacco G, Terracciano L, Fiocchi A, Restani P, Caroli AM (2011) Goat milk allergenicity as a function of alphas-casein genetic polymorphism. $J$ Dairy Sci 94: 998-1004. http://dx.doi.org/10.3168/jds.2010-3545

Bastos E, Cravador A, Azevado J, Guedes-Pinto H (2001) Single strand conformation polymorphism (SSCP) detection in six genes in Portuguese indigenous sheep breed "Churra da Terra Quente". Biotechnol Agron Soc Environ 5: 7-15.

Bevilacqua C, Helbling JC, Miranda G, Martin P (2006) Translational efficiency of casein transcripts in the mammary tissue of lactating ruminants. Reprod Nutr Dev 46: 567-578. http://dx.doi.org/10.1051) rnd:2006028

Ceriotti G, Chessa S, Bolla P, Budelli E, Bianchi L, Duranti E, Caroli A (2004) Single nucleotide polymorphisms in the ovine casein genes detected by polymerase chain reaction - Single strand conformation polymorphism. J Dairy Sci 87: 2606-2613. http://dx.doi.org/ 10.3168/jds.S0022-0302(04)73386-X
Chessa S, Rignanese D, Berbenni M, Ceriotti G, Martin M, Pagnacco G, Caroli A (2010) New genetic polymorphisms within ovine $\beta$ - and $\alpha \mathrm{s} 2$ caseins. Small Rumin Res 88: 84-87. http://dx.doi.org/10.1016/j.smallrumres.2009.12.014

Chianese L, Mauriello R, Ferranti P, Tripaldi C, Taibi L, Dell'Aquila S (1997) Relationship between $\alpha_{\mathrm{s} 1}$-casein variants and clotting capability of ovine milk, Proc. 2nd IDF Seminar Milk Protein Polymorphism, Palmerston North, New Zealand, 316-323 $\mathrm{pp}$

Corral JM, Padilla JA, Izquierdo M (2010) Associations between milk protein genetic polymorphisms and milk production traits in Merino sheep breed. Livest Sci 129: 73-79. http:/ /dx.doi.org/10.1016/j.livsci.2010.01.007

Corral JM, Padilla JA, Izquierdo M, Martinez-Trancon M, Parejo JC, Salazar J, Fernandez-Garcia FI (2013) Detection and genetic characterization of ovine $C S N 1 S 2 * B$ polymorphisms and their associations with milk production traits. Livest $S_{c i}$ 153: 10-19. http://dx.doi. org/10.1016/j.livsci.2013.01.008

De Gortari MJ, Freking BA, Cuthbertson RP, Kappes SM, Keele JW, Stone RT, Leymaster KA, Dodds KG, Crawford AM, Beattie CW (1998) A second-generation linkage map of the sheep genome. Mamm Genome 9: 204-209

Dove P (2000) Genetic polymorphisms in milk protein genes and their impact on milk composition. Adv Exp Med Biol 480: 225-230

Draganescu C (1997) Transhumance in Romania - past, present future Cuenca. Archiva Zootech 5: 15-23

Draganescu C, Grosu H (2010) Valachian (Zackel) heritage philetic sheep group - a taxonomic problem. In Scientific Papers of the Romanian Academy DAGENE, 1-7 pp.

FAO/IAEA (2004) Agriculture Biotechnology Laboratory - Handbook of Laboratory Exercises. IAEA Laboratories, Seibersdorf, 18 pp.

Gavojdian D, Cziszter LT, Sossidou E, Pacala N (2013) Improving performance of Zackel sheep through cross-breeding with prolific Bluefaced Leicester under semi-intensive and extensive production systems. I Appl Anim Res 41: 432-441. http://dx.doi.org/10.1080/ 09712119.2013.792734

Ilisiu E, Draban S, Radu R, Padeanu I, Ilisiu VC, Pascal C, Rahmann G (2012) The Romanian Tsigai sheep breed, their potential for organic cheese production. Agr Forest Res 362: 250-254

Leveziel H, Metenier L, Guerin G, Cullen P, Provot C, Bertaud M, Mercier JC (1991) Restriction fragment length polymorphism of ovine casein genes: close linkage between the $\alpha_{\mathrm{s} 1}, \alpha_{\mathrm{c} 2}-\beta$ - and $x$-casein loci. Anim Genet 22: 1-10. http://dx.doi.org/10.1111/j.1365-2052.1991. tb00641.x

Marletta D, Bordonaro S, Guastella AM, Falagiani P, Crimi N, D’Urso G (2004) Goat milk with different $\alpha$ s2-casein content: Analysis of allergenic potency by REAST-inhibition assay. Small Rumin Res 52: 19-24. http://dx.doi.org/10.3168/jds.2010-3545

Marletta D, Criscione A, Bordonaro S, Guastella AM, D’Urso G (2007) Casein polymorphism in goat's milk. Lait 87: 491-504. http:// dx.doi.org/10.1051/lait:2007034

Mroczkowski S, Korman K, Erhardt G, Piwczynski D, Borys B (2004) Sheep milk protein polymorphism and its effect on milk performance of Polish Merino. Arch Tiery 47: 114-121

Padeanu I (2001) Rearing technologies for sheep and goats (in Romanian). Timisoara: Mirton

Padeanu I, Sauer I, Sauer M, Voia O, Dumitrescu G (2004) Evolution of the body weight and absolute growing rate of Turcana $\mathrm{x}$ Ile de France hybrid from lambing up to 5 months of age. Biotechn Anim Husb, 20: 91-96

Pariset L, Capuccio I, Ajmone-Marsan P, Bruford M, Dunner S, Cortes O, Erhardt G, Prinzenberg EM, Gutscher K, Joost S, Pinto-Juma G, Nijman IJ, Lenstra JA, Perez T, Valentini A, ECONOGENE consortium (2006) Characterization of 37 breed-specific singlenucleotide polymorphisms in sheep. J Hered 97: 531-534. http:// dx.doi.org/10.1093/ihered/es1020

Park YW, Juarez M, Ramos M, Haenlein GFW (2007) Physico-chemical characteristics of goat and sheep milk. Small Rumin Res 68: 88113. http://dx.doi.org/10.1016/j.smallrumres.2006.09.013

Provot C, Persuy MA, Mercier JC (1995) Complete sequence of ovine $\beta$-casein-encoding gene and interspecies comparison. Gene 154: 259263. http://dx.doi.org/10.1016/0378-1119(94)00755-H

Sztankóová Z, Kyselova J, Rychtarova J, Czernekova V (2011) Technical note: A novel method for routine genotyping of the $G$ allele of $\beta$-casein (CSN2) and T allele of k-casein (CSN3) in a sheep population using LightCycler. I Anim Sci 89: 3843-3845. http://dx.doi. org/ 10.2527/jas.2011-4054

Threadgill DW, Womack JE (1990) Genomic analysis of the major bovine milk protein genes. Nucleic Acids Res 18: 6935-6942 